\title{
Murine Hybridoma Antibodies Enhance Bactericidal Activity of Human Cord Blood against K1 Escherichia coli Strains ${ }^{1}$
}

\author{
KWANG SIK KIM, ALAN S. CROSS, BENNETT KAUFMANN, WENDELL ZOLLINGER, AND \\ JERALD SADOFF \\ Department of Pediatrics, Childrens Hospital of Los Angeles, USC School of Medicine, Los Angeles, California \\ 90027 and Department of Bacterial Diseases, Walter Reed Army Institute of Research, Washington, DC 20307
}

\begin{abstract}
Murine hybridoma antibodies directed against the capsule and $\mathrm{O}$-side chain determinants of the Escherichia coli strain Bort (018ac:K1:H7) were evaluated for their ability to enhance bactericidal activity of cord blood against $\mathrm{K1} E$. coli strains possessing $\mathrm{O}$ antigens common in neonatal $E$. coli infection, i.e. 018, 07, and 01 . The antibodies to the $\mathrm{Kl}$ capsule and $\mathrm{O}$-side chain efficiently enhanced cord polymorphonuclear leukocyte-mediated killing of $\mathrm{K} 1$ encapsulated $E$. coli strain possessing a homologous $O$ antigen, but the IgM antibody to the $\mathrm{K} 1$ capsule exhibited approximately 10-fold greater activity than did the IgG3 antibody to $\mathrm{O}$-side chain (weight basis). Both antibodies required complement for their opsonic activities. Our findings indicate that antibodies directed against the capsule and $O$-lipopolysaccharides are able to restore the opsonic activity of cord blood against K1 $E$. coli, suggesting that these antibodies may be useful in the prevention and therapy of neonatal $E$. coli infection. ( $P e$ diatr Res 28: 667-670, 1990)
\end{abstract}

\section{Abbreviations}

CFU, colony forming units

LPS, lipopolysaccharide

PMN, polymorphonuclear leukocyte

In neonates, infections due to gram-negative bacilli are associated with significant morbidity and mortality despite appropriate antimicrobial therapy (1). The most common gram-negative organism causing sepsis and meningitis during the neonatal period is Escherichia coli (1). Given the plethora of $E$. coli serotypes (2), it is striking that $E$. coli strains possessing the $\mathrm{K} 1$ capsular polysaccharide are the predominant capsular serotype responsible for neonatal $E$. coli sepsis and meningitis (3-5) and that most of these $\mathrm{K} 1 \mathrm{E}$. coli isolates are associated with a limited number of O-LPS antigens (i.e. 018,07, 01, 016) (6).

We have developed a series of murine hybridomas producing $\mathrm{MAb}$ against different cell wall components of $\mathrm{K} 1$-encapsulated $E$. coli. MAb prepared against group B meningococcus and reactive with $E$. coli $\mathrm{K} 1$ polysaccharides and antibodies directed against $\mathrm{O}$-side chain determinants of a $\mathrm{K} 1 \mathrm{E}$. coli strain were

Received May 25, 1989; accepted July 18, 1990.

Correspondence and reprint requests: Kwang Sik Kim, M.D., Division of Infectious Diseases, Childrens Hospital of Los Angeles, 4650 Sunset Boulevard, Los Angeles, CA 90027.

Supported in part by R01-NS-26310 from the National Institute of Neurological and Communicative Disorders and Stroke.

' Presented at the Annual Meeting of the Society for Pediatric Research and the American Pediatric Society, May 1986, in Washington, DC. opsonic in vitro, and also protected newborn rats against a homologous $\mathrm{O}$ serogroup of $\mathrm{Kl}$ encapsulated $E$. coli $(7)$. The previous opsonic experiments used adult human PMN and fresh adult serum against $\mathrm{Kl}$-encapsulated $E$. coli strains possessing a homologous $\mathrm{O}$ serogroup. Our study evaluated whether these $\mathrm{MAb}$ could also provide opsonic activity of cord blood against $\mathrm{K} 1$ E. coli strains.

\section{MATERIALS AND METHODS}

Bacterial strains. Three serum-resistant $\mathrm{K} 1$-encapsulated $E$. coli strains were tested; C5 (018ac:K1:H7), C10 (07:K1:NM), and $\mathrm{A} 90(01: \mathrm{K} 1: \mathrm{H} 7)$. These strains were isolated from the cerebrospinal fluid of newborn infants with meningitis and were kindly provided by $\mathrm{R}$. Bortolussi of Dalhousie University, Halifax, Canada and M. Achtman of Max-Planck-Institute, Berlin, Germany $(8,9)$. The $E$. coli strains were grown in brain heart infusion broth (Difco Laboratories, Detroit, MI) to late logarithmic phase and were stored in aliquots at $-70^{\circ} \mathrm{C}$ until used.

Hybridoma antibodies. Two murine MAb were evaluated. Clone 19 was prepared against the whole organism of $E$. coli strain Bort (018ac:K1:H7), and secreted antibody of IgG3 class (10). This MAb reacts with the O-side chain of the LPS of Bort strain and does not react with LPS core determinants (11). Quantitation of antibody in ascitic fluid by a solid-phase RIA (12) revealed the presence of $1.4 \mathrm{mg} / \mathrm{mL}$ of $\mathrm{IgG}$ antibody. Clone 2-2-B was prepared against group B meningococcus and secreted IgM antibody specific for the capsular polysaccharides of group $\mathrm{B}$ meningococcus and $\mathrm{K} 1 E$. coli $(13)$. The ascitic fluid used in our experiment contained $3 \mathrm{mg}$ of the antibody $/ \mathrm{mL}$ as determined by a quantitative solid-phase RIA (12). For the purpose of the manuscript, this antibody is referred to as anti- $E$. coli $\mathrm{K} 1$ polysaccharide.

Human cord sera. Human cord sera were collected aseptically from deliveries of healthy, term infants, and only those that were free of maternal blood contamination (defined as IgM $<15 \mathrm{mg}$ / dL) were included in this study. Cord blood was allowed to clot at $0^{\circ} \mathrm{C}$ (in ice) and serum was stored in aliquots at $-70^{\circ} \mathrm{C}$ within 60 min of collection to preserve endogenous complement activity. At the time of in vitro studies, sera were examined for complement activity using a $\mathrm{CH} 100$ assay (Kallestad Laboratories, Austin, TX).

Opsonophagocytic assays. A total of 28 cord sera that met the above criteria were examined for the opsonic activity against three different strains of $\mathrm{K} 1 \mathrm{E}$. coli by the method described previously (7). Neutrophils were isolated from cord blood by dextran sedimentation followed by Ficoll-Hypaque density centrifugation. Frozen bacteria were thawed, diluted (1:20) in fresh prewarmed brain heart infusion broth, and grown at $37^{\circ} \mathrm{C}$ for approximately $4 \mathrm{~h}$ to match the turbidity of a MacFarland no. 0.5 standard (14). This late logarithmic culture was washed and 
resuspended in a concentration of $1 \times 10^{8} \mathrm{CFU} / \mathrm{mL}$. Washed neutrophils (approximately $1 \times 10^{6} \mathrm{PMN} / 40 \mu \mathrm{L}$ ) were added to a $12 \times 75 \mathrm{~mm}$ sterile polystyrene tube (Falcon Plastics, Oxnard, CA) along with $10 \mu \mathrm{L}$ of washed logarithmic-phase $E$. coli (approximately $1 \times 10^{6} \mathrm{CFU}$ ), $10 \mu \mathrm{L}$ of cord sera, $10 \mu \mathrm{L}$ of MAb, and $30 \mu \mathrm{L}$ of minimal essential medium with Earles' balanced salt solution (GIBCO Laboratories, Santa Clara, CA) in a total volume of $100 \mu \mathrm{L}$. The same minimal essential medium was used in washing and resuspending PMN and bacteria and as a diluent of antibodies. The final mixture contained a ratio of PMN to bacteria of approximately $1: 1$. Control tubes lacking either PMN, cord sera, or antibody were also included in each experiment. In some experiments, cord serum heated at $56^{\circ} \mathrm{C}$ for $1 \mathrm{~h}$ was included as a control. Tubes were incubated at $37^{\circ} \mathrm{C}$ with end-over-end rotation using a multipurpose rotator (Scientific Industries, Inc., Springfield, MA). Aliquots $(10 \mu \mathrm{L})$ were taken from each tube at 0 and $1 \mathrm{~h}$, serially diluted 10 -fold in sterile distilled water, and plated on blood agar for determination of surviving CFU. Results were expressed as the percentage of bacteria killed: $100-[(\mathrm{CFU}$ at $1 \mathrm{~h} / \mathrm{CFU}$ at $0 \mathrm{~h}) \times 100]$.

Statistical methods. Fisher's exact test, nonparametric Wilcoxon signed rank test, or paired $t$ test was used where indicated (15).

\section{RESULTS}

Opsonic activity of cord sera after addition of IgM antibody reactive with $K 1$ polysaccharide. In opsonophagocytic assays, bacterial killing did not occur in control tubes lacking either PMN, cord serum, or antibody. Thus, phagocytosis and killing of serum-resistant $\mathrm{K} 1 \mathrm{E}$. coli strains require PMN, heat-labile serum factors (presumably complement), and specific antibody. $\mathrm{MAb} 2-2-\mathrm{B}$, reactive with group B meningococcal and $E$. coli $\mathrm{K} 1$ polysaccharides, was highly effective in enhancing opsonic activity of cord sera and its activity was optimal at 50-500 ng/ $\mathrm{mL}$ of the antibody. We previously showed that the activity of this MAb was specific by providing protection against $E$. coli strains possessing the $\mathrm{K} 1$ polysaccharide, but not against non$\mathrm{K} 1 \mathrm{E}$. coli (e.g. K92 strain, 16). Overall, enhancement of cord PMN-mediated killing appeared to be greater with strain A90 than with strain $\mathrm{C} 5$ or $\mathrm{C} 10$ (Fig. 1). With the addition of $50 \mathrm{ng} /$ $\mathrm{mL}$ of anti- $E$. coli $\mathrm{K} 1$ antibody, the mean $( \pm \mathrm{SE})$ of killing after $1 \mathrm{~h}$ incubation of strain $\mathrm{A} 90$ was $97 \pm 0.2$ versus $83 \pm 4.2 \%$ killing for strain C5 and $85 \pm 2.4 \%$ killing for strain $\mathrm{C} 10$ ( $p<$ 0.005 comparing A90 to the other two strains). Efficient opson-

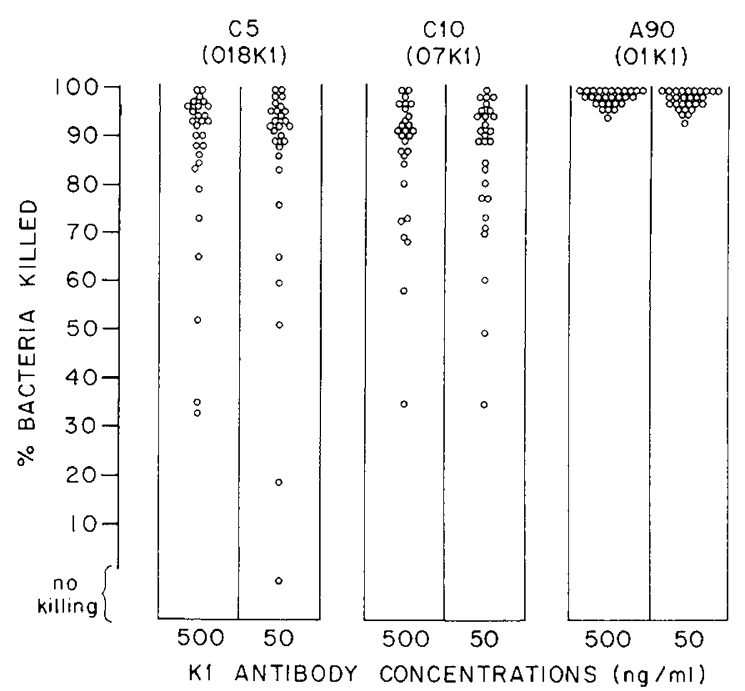

Fig. 1. Opsonophagocytic killing of serum resistant $\mathrm{K} 1$ E. coli strains C5 (018:K1), C10 (07:K1), and A90 $(01: \mathrm{K} 1)$ by 28 cord sera in conjunction with cord PMN and IgM MAb to the K1 capsule. No killing was observed in the absence of serum, PMN, or MAb. ophagocytosis and killing (defined as $\geq 80 \%$ killing of the original inoculum at $1 \mathrm{~h}$ of incubation) in the presence of 50 or $500 \mathrm{ng} /$ $\mathrm{mL}$ of the antibody was noted in 100,78 , and $86 \%$ of the 28 cord sera tested against strains $\mathrm{A} 90, \mathrm{C} 5$, and $\mathrm{C} 10$, respectively $(p>0.1)$. Demonstration of efficient opsonic activity of cord blood in the presence of $50-500 \mathrm{ng} / \mathrm{mL}$ of the antibody was not directly correlated with $\mathrm{CH} 100$ values; of the 20 cord sera exhibiting $\geq 80 \%$ killing against three strains of $\mathrm{K} 1 \mathrm{E}$. coli, 12 $(60 \%)$ contained $>70 \mathrm{CH} 100 \mathrm{U} / \mathrm{mL}$ (normal range), whereas three $(37.5 \%)$ of eight cord sera exhibiting $<80 \%$ killing against one or more of the three Kl $E$. coli strains also contained $>70$ $\mathrm{CH} 100$.

Opsonic activity of cord sera after addition of $\operatorname{Ig} G$ antibody reactive with 018-LPS. We next examined the opsonophagocytic activity of cord PMN and cord sera after the addition of IgG3 anti-LPS MAb reactive with $\mathrm{K} 1 \mathrm{E}$. coli strains possessing the 018 serotype. As expected, the opsonic activity of this anti-LPS MAb in the presence of cord sera was serotype-specific and its opsonic activity was demonstrated only against strain C5 (018:K1) and not C10 (07:K1) or A90 (01:K1) (Fig. 2). As shown previously (7), a prozone effect was observed with the LPS antibody in concentrations $>5000 \mathrm{ng} / \mathrm{mL}$. Optimal killing occurred at 500 $\mathrm{ng} / \mathrm{mL}$ for all 28 cord sera tested. The mean $( \pm \mathrm{SE})$ bacterial killings at the LPS antibody of 500 and $5000 \mathrm{ng} / \mathrm{mL}$ were, respectively, $81 \pm 2.9$ and $64 \pm 4.9 \%$, and this difference was significant $(p=0.0004)$. When assays were done with $500 \mathrm{ng} /$ $\mathrm{mL}$ of the antibody, efficient opsonophagocytosis and killing ( $\geq 80 \%$ killing of the original inoculum at $1 \mathrm{~h}$ of incubation) occurred in 19 of $28(68 \%)$ cord sera.

One interesting observation was that the two MAb interacted independently with some cord sera for opsonophagocytosis and killing of strain C5. For example, nine of the 28 cord sera tested failed to exhibit $\geq 80 \%$ killing of strain C5 in the presence of 500 $\mathrm{ng} / \mathrm{mL}$ of IgG3 anti-LPS antibody. Of these nine sera, seven supported killing of $\geq 80 \%$ with 50 or $500 \mathrm{ng} / \mathrm{mL}$ of the IgM antibody reactive with the $\mathrm{K} 1$ polysaccharide. Conversely, six of the 28 cord sera failed to support $\geq 80 \%$ killing of strain $\mathrm{C} 5$ after the addition of $\operatorname{IgM}$ anti-K1 antibody. Of these six, four were

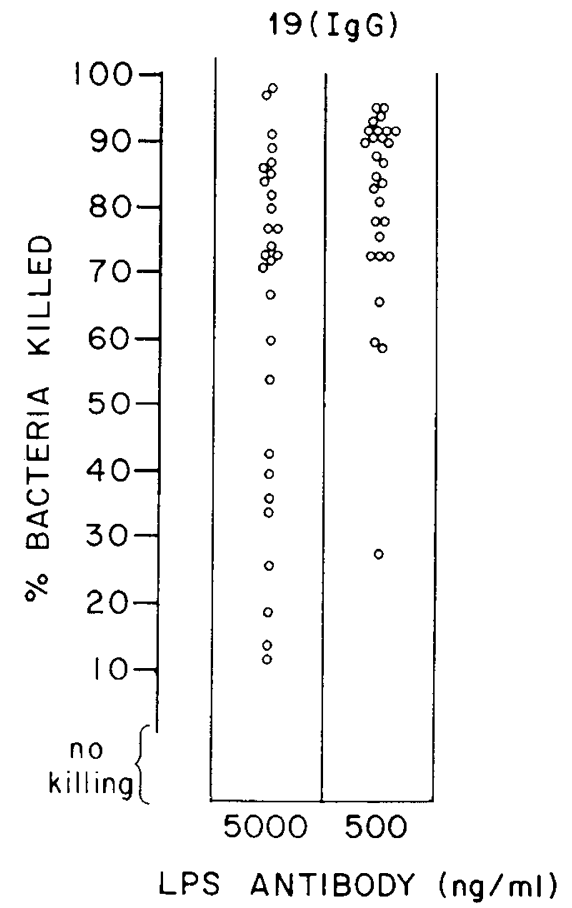

Fig. 2. Opsonophagocytic killing of a serum-resistant $\mathrm{K} 1$ E. coli strain C5 $(018: \mathrm{K} 1)$ by 28 cord sera in conjunction with cord PMN and IgG3 $\mathrm{MAb}$ to a homologos serotype (018). No killing was observed in the absence of serum, PMN, or MAb, nor against $\mathrm{K} 1$ E. coli strains possessing a heterologous O serogroup (e.g., 07, 01). 
Table 1. Demonstration of opsonic activity of 13 cord sera against serum-resistant K1 E. coli strain C5 (018:K1) by MAb directed against $K 1$ capsular polysaccharide or homologous O serotype (018)

\begin{tabular}{cccc} 
& & \multicolumn{2}{c}{$\begin{array}{c}\text { \% Bacteria } \\
\text { killed } \dagger\end{array}$} \\
\cline { 3 - 4 } Cord serum no. & $\mathrm{CH} 100(\mathrm{U} / \mathrm{mL})^{*}$ & 018 & $\mathrm{K1}$ \\
\hline 15 & 63 & 59 & 95 \\
20 & $>175$ & 60 & 95 \\
$9 \mathrm{~S}$ & 55 & 66 & 91 \\
$1 \mathrm{~S}$ & 85 & 73 & 97 \\
$8 \mathrm{~S}$ & 65 & 73 & 90 \\
22 & 44 & 74 & 99 \\
$6 \mathrm{~S}$ & 71 & 78 & 99 \\
$10 \mathrm{~S}$ & 95 & 91 & 35 \\
$3 \mathrm{~S}$ & 65 & 81 & 65 \\
24 & 63 & 90 & 73 \\
30 & 49 & 85 & 79 \\
7 & 112 & 78 & 66 \\
31 & 85 & 28 & 76 \\
\hline
\end{tabular}

$*>70 \mathrm{CH} 100 \mathrm{U} / \mathrm{mL}$ is considered normal range.

$\dagger$ Percent of the original inoculum killed in the presence of $500 \mathrm{ng} /$ $\mathrm{mL}$ of the $\mathrm{IgG} 3$ antibody to 018 , or 50 or $500 \mathrm{ng} / \mathrm{mL}$ of the IgM antibody to the $\mathrm{K} 1$.

able to exhibit $\geq 80 \%$ killing with $500 \mathrm{ng} / \mathrm{mL}$ of the IgG3 antiLPS antibody. This salutary effect on opsonic activity of cord sera by MAb directed against the capsule and O-LPS was not directly correlated with $\mathrm{CH} 100$ values (Table 1).

\section{DISCUSSION}

Our studies revealed that murine IgM MAb directed against the $E$. coli $\mathrm{K} 1$ capsule efficiently enhanced cord serum/PMNmediated killing of $\mathrm{K} 1 \mathrm{E}$. coli strains regardless of their $\mathrm{O}$ serotypes. Further, murine IgG3 MAb to O-LPS components of $\mathrm{K} 1 E$. coli was able to support cord serum/PMN-mediated killing of $E$. coli strain possessing a homologous $\mathrm{O}$ serotype even in the presence of the K1 capsule. These findings corroborate those of Cross et al. (17) who have shown that PMN obtained from cord blood in conjunction with specific anticapsular antibody and complement can kill K1-encapsulated $E$. coli strains. Our data suggest that IgM antibody directed against the $\mathrm{K} 1$ capsule is more effective in providing opsonic activity against $\mathrm{K} 1 E$. coli strains than IgG3 antibody directed against O-LPS, as shown by approximately 10 -fold less antibody required for efficient opsonic activity by the former than the latter. These findings are consistent with those of our previous studies using adult PMN (7). Whether this difference in complement-mediated enhancement of PMN killing reflects the different antigenic targets of the two antibodies or the different isotypes requires further investigation. Previous studies using Haemophilus influenzae type b indicate that IgM antibody to the type b capsule is more active on a weight basis than IgG antibody in enhancing complement-mediated bacterial lysis in the absence of PMN (18). However, IgG antibody appears to be more active than IgM antibody in enhancing PMN phagocytosis (18).

In our study, the addition of increasing amounts of IgG3 anti$O$ LPS antibody resulted in less bacterial killing, but a similar phenomenon was not observed at the two IgM anti-K1 antibody concentrations tested (Fig. 1). Using different opsonophagocytic assays and adult PMN $(7,13)$, we have previously shown that $\mathrm{MAb}$ directed against both the $\mathrm{K} 1$ capsule and O-LPS in excess of $600 \mu \mathrm{g} / \mathrm{mL}$ were unable to support adult PMN-mediated killing of $\mathrm{K} 1 E$. coli strain (7). The in vivo significance of this prozone phenomenon is not established, but our data suggesting that a prozone may occur with anti-LPS antibody concentrations as low as $5 \mu \mathrm{g} / \mathrm{mL}$ suggest that further studies of the mechanism and biologic relevance of this phenomenon may be warranted.
One interesting finding in our study was that although the overall ability to provide opsonic activity of cord sera was more effective with the IgM anticapsular antibody than with the $\operatorname{IgG} 3$ anti-O-LPS antibody, efficient opsonic activity was achieved in some sera only with the anti-O-LPS antibody (Table 1). The reasons for this apparent discrepant interaction of anti-O-LPS antibody with cord sera are unclear. We previously showed in the experimental $E$. coli infection that the combination of antibodies to the capsule and O-LPS was more beneficial than either antibody alone because it provided significantly greater protection from bacteremia and death (7). Thus, one potential explanation for the greater activity observed with the anti-O-LPS antibody in some cord sera may be that these cord sera contain suboptimal concentrations of other opsonic antibodies. Thus, although these sera did not exhibit efficient opsonic activity by themselves, endogenous antibody directed against different cell wall components (e.g. capsule) may have interacted with the $\mathrm{MAb}$ added to the reaction and resulted in efficient opsonophagocytosis and killing of a homologous K1 E. coli. Additional studies are needed measuring directly the presence of such antibodies or using cord sera absorbed with non-LPS structures (e.g. capsule) to refute this possibility. Nevertheless, our findings support the concept that IgG antibody to O-LPS may be useful for passive immunotherapy of neonatal $\mathrm{K} 1 \mathrm{E}$. coli infection. This information is particularly valuable because the number of $\mathrm{O}$ antigens common in neonatal $E$. coli sepsis and meningitis are limited (6) and techniques for preparing hyperimmune globulin-containing antibodies against several $\mathrm{O}$ antigens are available.

Overall, our studies indicate that cord PMN and sera are deficient in exhibiting opsonic activity against $\mathrm{K} 1 \mathrm{E}$. coli strains possessing $\mathrm{O}$ antigens commonly associated with neonatal sepsis and meningitis (i.e. 018,07, and 01) and that antibodies directed against the capsule and O-LPS can restore the opsonic activity of cord blood against these K1 E. coli strains. However, use of antibody preparations to the $\mathrm{K} 1$ polysaccharide or efforts to improve the K1 polysaccharide's immunogenicity must be pursued with caution. Certain structures (e.g. gangliosides, glycopeptides) in the human fetal and newborn brain contain sialic acid with the same $\alpha$-2,8-linkage as $E$. coli $\mathrm{K} 1$ polysaccharides (1820 ). Thus, there is some concern whether antibodies to the $K 1$ polysaccharide may bind to host tissues and have a harmful effect (21).

Acknowledgments. The authors thank Jane Hong for technical assistance and Caroline Rivera for typing the manuscript.

\section{REFERENCES}

1. Siegel JD, McCracken Jr GH 1981 Sepsis neonatorum. N Engl J Med 304:642 647

2. Orskov I, Orskov F, Jann B, Jann K 1977 Serology chemistry and genetics of $\mathrm{O}$ and $\mathrm{K}$ antigens of Escherichia coli. Bacteriol Rev 41:667-683

3. Robbins JB, McCracken Jr GH, Goschlich EC, Orskov F, Orskov I, Hanson LA 1974 Escherichia coli $\mathrm{K} 1$ capsular polysaccharide associated with neonatal meningitis. N Engl J Med 290:1216-1220

4. Gross RJ, Ward LR, Threlfall EJ, Cheasty T, Rowe B 1983 Drug resistance among Escherichia coli strains isolated from cerebrospinal fluid. $J$ Hyg 90:195-198

5. Korhonen TK, Valtonen MV, Parkkinen J, Vaisamem-Rhen V, Finne J, Orskov F, Orskov I, Svenson SB, Makela PH 1985 Serotypes, hemolysin production, and receptor recognition of Escherichia coli strains associated with neonatal sepsis and meningitis. Infect Immun 48:486-491

6. Sarff LC, McCracken GH Jr, Schiffer MS, Glode MO, Robbins JB, Orskov I, Orskov F 1975 Epidemiology of Escherichia coli $\mathrm{K}$ in healthy and diseased newborns. Lancet 1:1099-1104

7. Kim KS, Kang JH, Cross AS, Kaufman B, Zollinger W, Sadoff J 1988 Functional activities of monoclonal antibodies to the $\mathrm{O}$ side chain of Esch erichia coli lipopolysaccharides in vitro and in vivo. J Infect Dis 157:47-53

8. Bjorksten B, Bortolussi R, Gothefors L, Quie PG 1976 Interaction of E. coli strains with human serum: lack of relationship to $\mathrm{Kl}$ antigen. $J$ Pediatr 89:892-897

9. Achtman M, Mercer A, Kusecek B, Pohl A, Henzenroeder M, Aaronson W, Sutton A, Silver RP 1983 Six widespread bacterial clones among Escherichia coli $\mathrm{K}$ isolates. Infect Immun 39:315-335 
10. Kaufman BM, Cross AS, Futrovsky SL, Sidberry HF, Sadoff JC 1986 Monoclonal antibodies reactive with K1-encapsulated Escherichia coli lipopolysaccharide are opsonic and protect mice against lethal challenge. Infect Immun 52:617-619

11. Sidberry H, Kaufman B, Wright DC, Sadoff J 1985 Immunoenzymatic analysis by monoclonal antibodies of bacterial lipopolysaccharides after transfer to nitrocellulose. J Immunol Methods 76:299-305

12. Zollinger WD, Boslego JW 1981 A general approach to standardization of the solid-phase radioimmunoassay for quantitation of class-specific antibodies. J Immunol Methods 46:129-140

13. Cross AS, Zollinger W, Mandrell R, Gemski P, Sadoff J 1983. Evaluation of immunotherapeutic approaches for the potential treatment of infections caused by K1-positive Escherichia coli. J Infect Dis 147:68-76

14. Kim KS, Anthony BF 1983 Efficacy of trimethoprim/sulfamethozazole in experimental Escherichia coli bacteremia and meningitis. Chemotherapy 29:428-435

15. Snedecor GW, Cochran WG 1967 Statistical methods, 6th Ed. Iowa State University Press, Ames, lowa
16. Kim KS, Cross AS, Zollinger W, Sadoff J 1985 Prevention and therapy of experimental Escherichia coli infections with monoclonal antibody. Infect Immun 50:734-737

17. Cross AS, Woodlridge WH, Zollinger WD 1984 Monoclonal antibody 2-2-B kills K1-positive Escherichia coli in conjunction with cord blood neutrophils and sera, but not with spinal fluid. Pediatr Res 18:770-772

18. Schreiber JR, Barrus V, Cates KL, Siber GR 1986 Functional characterization of human IgG, IgM, and IgA antibody directed to the capsule of Haemophilus influenzae type b. J Infect Dis 153:8-15

19. Finne J, Leionen M, Makela PH 1983 Antigenic similarities between brain components and bacteria causing meningitis. Implications for vaccine development and pathogenesis. Lancet 2:335-357

20. Soderstrom T, Hansson G, Larson G 1984 The Escherichia coli K1 capsule shares antigenic determinants with the human gangliosides GM3 and GD3. N Engl J Med 310:726-727

21. Institute of Medicine 1986 The Prospects for immunizing against Neisseria Meningitidis. In: New Vaccine Development, Establishing Priorities, Vol II. Diseases of Importance in Developing Countries. National Academic Press, Washington, DC, pp 251-266

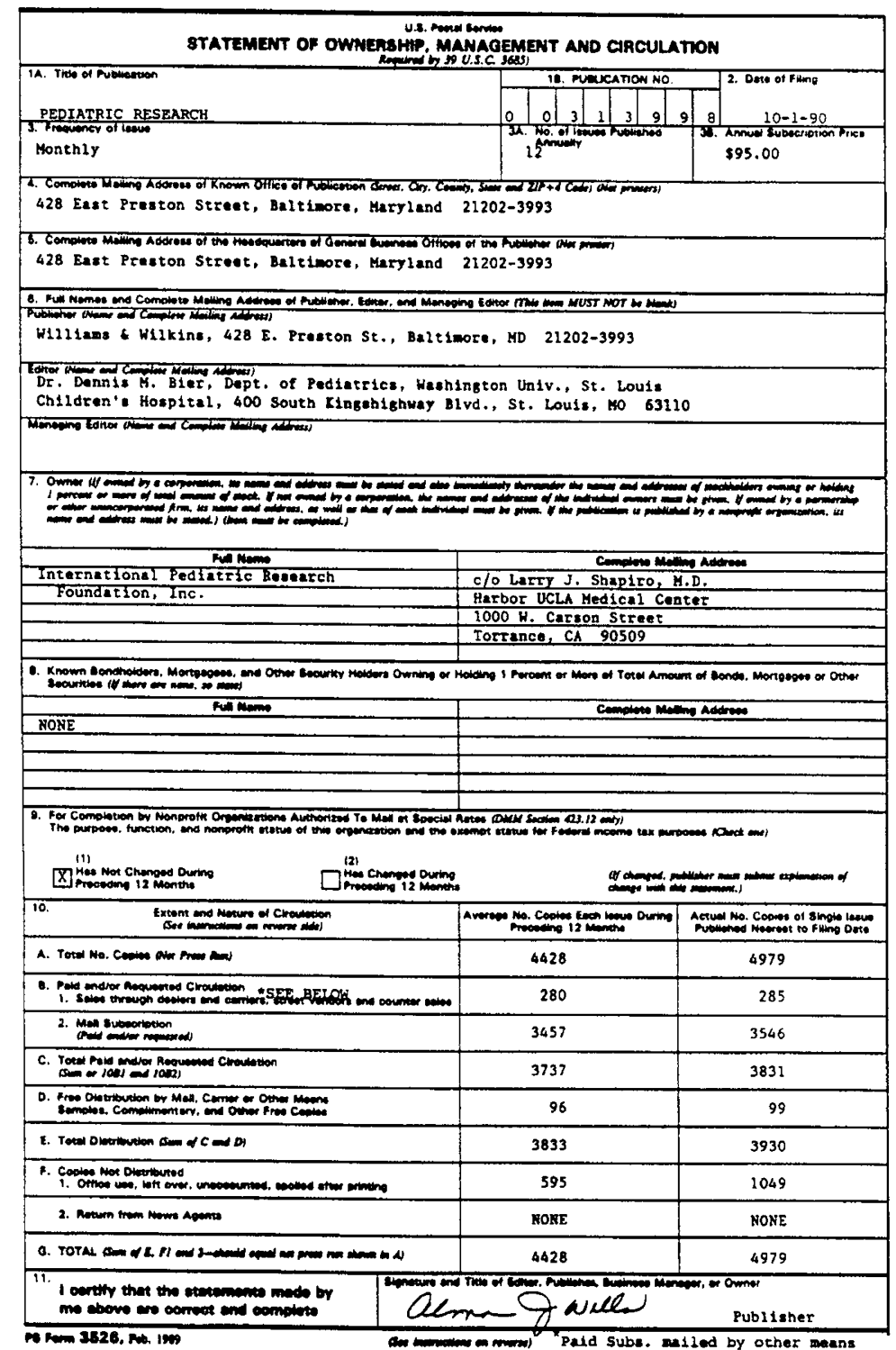

